\title{
Self-Efficacy, Meaning of Work as Vocation, and Work Engagement of High School Teachers in Surabaya
}

\author{
Adi Satria Indramawan \\ Faculty of Psychology \\ Universitas Surabaya
}

\begin{abstract}
A teacher with self-efficacy is more able to accomplish any task from the management so that he is engaged to his work, and a teacher who regards his work as a calling has the proper motivation to work better. The aim of this study was to find whether there is a correlation between teacher's self-efficacy and work engangement and whether there is a correlation between the meaning of work as a calling and work engagement of private high school teachers in Surabaya. The subjects $(N=87)$ were teachers from three private schools in Surabaya. The data was collected through close-ended statements scales with five options of answer that were later analyzed through a nonparametric correlation test with SPSS 19.00. The result showed a correlation between teachers' self-efficacy and work engagement $(r=.08 ; p$ $<.05)$ and a correlation between the meaning of work as a calling and work engagement $(r=$ $.612 ; p<.05)$. Based on the result, it could be concluded that teachers' self efficacy and meaning of work as a calling could not be treated as one unit, but each correlated independently with their work engagement.
\end{abstract}

Keywords: work engagement, teachers' self-efficacy, meaning of work as a calling

Guru dengan keyakinan diri lebih mampu melaksanakan tugas apa pun dari manajemen sehingga dia terikat dengan pekerjaannya, dan guru yang menghayati pekerjaannya sebagai suatu panggilan hidupnya memiliki motivasi yang sesuai untuk bekerja lebih baik. Tujuan studi ini adalah mengamati apakah ada korelasi antara keyakinan diri seorang guru dan keterikatan kerja dan apakah ada korelasi antara makna bekerja sebagai panggilan dan keterikatan kerja, pada guru-guru di SMA swasta di Surabaya. Para subjek $(N=87)$ merupakan para guru di tiga sekolah swasta di Surabaya. Data dikumpulkan melalui skala pernyataan tertutup dengan lima opsi jawaban yang kemudian dianalisis dengan uji korelasi nonparametric memakai SPSS 19.00. Hasil menunjukkan korelasi antara keyakinan diri guru dan keterikatan kerja $(r=.08 ; p<$ $.05)$ dan korelasi antara makna bekerja sebagai panggilan dan keterikatan kerja $(r=.612 ; p<$ .05). Berdasarkan hasil tersebut dapat disimpulkan bahwa keyakinan diri guru dan makna bekerja sebagai panggilan tak dapat diperlakukan sebagai satu kesatuan, namun berkorelasi secara mandiri dengan keterikatan kerja masing-masing.

Kata kunci: keterikatan kerja, keyakinan diri guru, makna bekerja sebagai panggilan

The Surabaya's City Education Council created an online journal for teachers to give them an opportunity to contribute their scientific writings and to maintain their academic quality. Another effort from the Department of Education was to socialize the 2013 curriculum; despite the pros and cons in the implementation. At the launching of that online journal:

The Mayor of Surabaya Trirismaharini in her re-

Correspondence concerning this article should be addressed to Adi Satria Indramawan, Faculty of Psychology Universitas Surabaya, Jalan Raya Kalirungkut, Surabaya 60293. E-mail: adi5100829@gmail.com marks stated that, teachers in Surabaya held the 'Key of Heaven,' because the work of teachers in Surabaya was a noble work, in addition to imparting knowledge to the students, teachers could also give their students moral education so that they would become the best persons for their homeland, nation, and religion. The former Educational Minister M. Nuh took the opportunity to emphasize that Surabaya should be the pioneer in eradicating school dropout (Humas Dispendik Surabaya, 2013).

One indicator in education is the educators or teach- 
ers, because they directly interact with students. Direct interaction between teachers and students creates a development for teachers in producing students with vast knowledge and high morality. Teachers are professional educators, with the main duty to educate, teach, guide, direct, train, assess, and evaluate students in early childhood education, formal education, primary education, and secondary education (UndangUndang RI, 2006).

According to Leiter \& Bakker (2010) work engagement is a motivational concept. A worker who is engaged to his work will be absorbed in the work so that he will not be easily distracted during work and he will feel that working time was too short. Work engagement is a positive, satisfying, and work-related state of mind that is characterized by vigor, dedication, and absorption (Schaufeli, Salanova, GonzalezRoma, \& Bakker, 2002a). Work engagement is not an easy thing, so problems can arise. Problems of teachers' work engagement was explained in the three aspects of work engagement in the research of Klassen, Yerdelen, Durksen (2013); Hakanen, Bakker, Schaufeli (2006) and Baskin (2007) shown in Table 1.

Based on a preliminary interview conducted by the author to one of the teachers of Y High School in Surabaya, there was a problem in vigor related to their work engagement. The following is the excerpt of the interview:

For the time I work as a teacher here... there are times when I feel unmotivated or lacking in spirit... during the times when I have to work until late at night, because I have to prepare midtest or final test. (T, 14 November 2013)

Dedication is defined as being strongly involved in a work, experiencing a sense of enthusiasm, pride, and inspired by works. P shows a sense of lacking in challenge and inspiration to teacher's work. The following is the excerpt of the interview done by the author to one of the teachers:
I often feel unchallenged when I teach. I teach merely what are trusted to me. After teaching bla..bla..bla.. finishing the material and after that I'm done.

(P, 17 Oktober 2013).

Absorption is characterized by being fully concentrated and happily engrossed in one's work, whereby time passes quickly (Schaufeli, Bakker, \& Salanova, 2006). The following is the excerpt of interview conducted by the author to one of Y High School teachers:

When I was a vice principle, I usually went home late. That made my child said that mother was a workaholic he said. But I usually felt so tired, a little bit sleepy because I felt that I got more responsibilities. (T, 14 November 2013)

One of the factors in psychological resources is self-efficacy (Xanthopoulo, Bakker, Demerouti, \& Schaufeli, 2007). This statement is supported by Halbesleben's meta-analysis research (2010) which argued that psychological resources are associated with work engagement, specifically the self-efficacy has the coefficient correlation of .50. Someone who works must have a self-efficacy to finish the task. In teaching profession, the duty of a teacher is not only to teach but also to guide, to instill norms and values, and to evaluate.

Self-efficacy is defined as a belief about one's ability to exert motivation, cognition, as an action to accomplish specific tasks (Stajkovic \& Luthans, as cited in Ouweneel, Le Blanc, \& Schaufeli, 2012). According to Bandura (1977) self-efficacy is defined as a belief that contributes to the motivation, which affects individual's efforts and persistence when facing problems and unexpected conditions. The following is an excerpt of interview conducted by the author to one of Y High School teachers that depicts the lack of self-efficacy:

Parents entrust their kids to this school because this is a religion-based school... they're expecting us to properly build up their kids' morality. But if

Table 1

Problems in Work Engagement

\begin{tabular}{|c|c|c|}
\hline Research & Aspect & Discrepancy \\
\hline \multirow{3}{*}{$\begin{array}{l}\text { Klassen, Yerdelen, } \\
\text { Durksen (2013) } \\
\text { Hakanen, Bakker, } \\
\text { Schaufeli (2006) } \\
\text { Baskin (2007) }\end{array}$} & Vigor & $\begin{array}{l}\text { Teachers do not have high levels of energy, they } \\
\text { lack in willingness and persistence to make an } \\
\text { extra effort when facing difficulties. }\end{array}$ \\
\hline & Dedication & $\begin{array}{l}\text { Many teachers are not enthusiastic, they lack pride } \\
\text { in their work, and feel unchallenged. }\end{array}$ \\
\hline & Absorption & $\begin{array}{l}\text { Teachers often complain about the long work } \\
\text { hours, they lack focus, and they are unable to } \\
\text { concentrate when teaching. }\end{array}$ \\
\hline
\end{tabular}


the efforts are not supported by proper parental efforts at home, it's useless. That's why I feel that it's so hard to tell the parents to do their part in educating their children at home; not many parents are responding the request. (P, 17 October 2013)

A worker's view towards his profession or work can affect his working performance. This view is called the meaning of work. The meaning of work is defined as a worker's understanding of what he does in the work place and the meaning that he gives to what he does (Wrzesniewski, Dutton, \& Debebe, 2003). The general assumption of meaning of work is that individuals are inclined to compose their framework through different ways (Wrzesniewski, Dutton, \& Debebe).

According to Wrzesniewksi, McCaulley, Rozin \& Schwartz (1997) the meaning of work can be divided into three orientations namely job, career, and calling. The meaning of work as a calling is mostly used in religious contexts, people who understand about the meaning of work as a calling will feel as being called by "God" and do moral and social works (Weber, as cited in Wrzesniewski, McCaulley, Rozin \& Schwarts, 1997). People who give meaning to their work as a calling will see their job as a fulfillment of societal values and will be more engaging in activities (Wrzesniewski, McCaulley, Rozin \& Schwartz).

Bellah (cited in Wrzesniewski, McCaulley, Rozin \& Schwartz, 1997) stated that workers who regard their works as calling will not be too concerned about raise or financial award, but to the fulfillment of their work result. Individuals who do their works and define themselves as workers contribute and able to make their workplaces as a better world (Wrzesniewski, McCaulley, Rozin \& Schwartz). The following is an interview excerpt of a teacher who did not interpret his work as a calling:

So I didn't have a choice but to teach, and that's why I became a teacher. From the beginning, I didn't have any plan to be a teacher, I was told that in order to get into IKIP I didn't have to be a teacher.

The preliminary survey results of the study has shown that not all teachers had the motivation in their psychological resources, resulting in the lack of interest in High School X, High School Y, and High School $\mathrm{Z}$ teachers. Based on the description above, the author wanted to know the correlation between teachers' self-efficacy and their meaning of work as a calling and the teachers' work engagement. The selection of variables was supported by previous researches and preliminary survey data.

There are several factors that affect work engagement, but in this study it was only limited to the corre- lation between self efficacy and the meaning of work as a calling and work engagement. The three aspects of the variable meaning of work were calling, career, and job. The theory used in this study for the variable work engagement refers to the theory of Schaufeli, Salanova, Gonzales-Roma, \& Bakker (2002a), the meaning of work variable refers to the theory of Wrzesniewki, McCauley, Rozin, \& Schwartz (1997), and the variable of the self efficacy refers to Bandura's concept (1997). The two aims of this study were: (1) to find the correlation between meaning of work and work engagement of the teachers of High School X, High School Y, and High School Z; and (2) to find the correlation between self-efficacy and work engagement of the teachers of X High School, Y High Shool, and Z High School.

Several earlier studies that can be used as a comparison to this study are: Ines Muhartoyo's research (2009), "The Relationship Between Self-Efficacy and Work Engagement with Workload and Emotional Labor as a Moderator Variable of the Nurses of Mitra Keluarga Hospital in Surabaya" and Regina Martha Tanudjaja's research (2013), "The Relationship Between Family Conflict and Perception Towards Organizational Support with the Teachers' Work Engagement."

\section{Literature Reviews}

\section{Work Engagement}

According to Schaufeli, Salanova, Gonzales-Roma, \& Bakker (2002a), work engagement is a positive, fulfilling, and work-related state of mind that is characterized by vigor, dedication, and absorption. A work-engaged worker will have a high spirit and enthusiasm during his work, moreover an absorbed worker will feel that time passes quickly (Bakker \& Demerouti, 2008). This is a development of the emergence of positive psychology, which focuses on the strength of someone who can function optimally (Seligman \& Csikszentmihalyi, 2000). Studies on work engagement have shown empirical evidence that it is different with burnout and workaholism (Schaufeli, Taris, \& Van Rhenen, as cited in Hallberg \& Schaufeli, 2006). The concept of work engagement is a part of the welfare characteristics of working with a high level of energy, ethusiasm, dedication and commitment that will engage a worker.

Schaufeli, Martinez, Marquez-Pinto, Salanova, \& Bakker (2002b) stated that work-engagement has three characteristics. Firstly, the element of spirit that is characterized by a high energy and mental excite- 


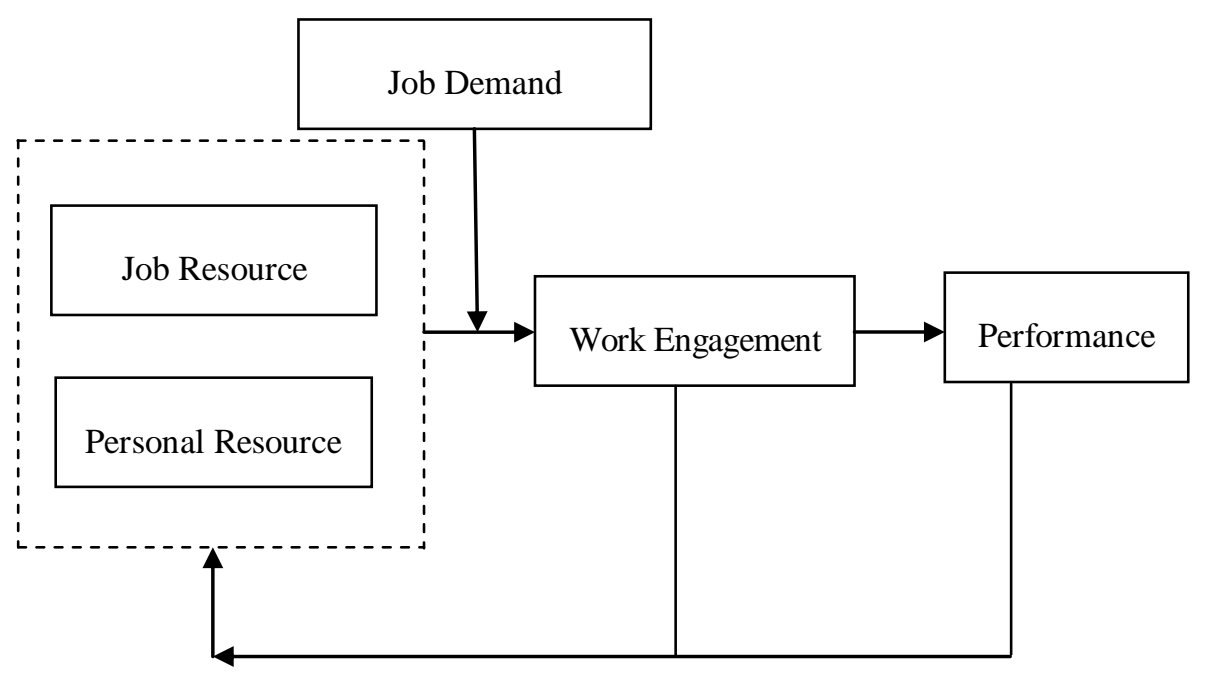

Figure 1. JD-R theory (Job demand-resources).

ment during work. Secondly, it has the element of dedication that leads to a high involvement in a job, followed by enthusiasm, pride, inspiration, and feeling challenged during work. Thirdly, it has the element of appreciation characterized by being fully concentrated and happily engrossed in one's work, whereby time passes quickly and one has difficulties with detaching oneself from work even for a while.

According to Kahn (1990) personal engagement, which is the utilization of members of an organization through its role in the organization, will engage the organization members so that they will express themselves physically, cognitively, and emotionally in carrying out their roles. Meanwhile personal disengagement was defined by Kahn as a detachment of oneself from his role in an organization, which is characterized by self-withdrawal or physical, cognitive, and emotional retreat in carrying out his role. Someone's work condition is not only affected by physical condition, but also the psychological condition.

Work engagement, according to Schaufeli et al. (2002a), uses two dimensions of work identification that related to welfare. First, activation from fatigue to vigor. Second, identification from cynicism to dedication. Work engagement is characterized by the existence of high levels of energy and identification that are related to work. In contrast burnout is characterized by the low level of energy and work-related identification (Schaufeli, Taris, Le Blanc, Peeters, Bakker, \& De Jonge 2001).

From the several explanations above, the author focused the definition of work engagement on the definition according to Masclach, Scaufeli, \& Leiter (2001) who define work engagement as a persistence, motivational fulfillment and positive feeling about work that is categorized into vigor, dedication, and absorption. This definition was chosen because it covered the entire definition of work engagement. Vigor is characterized by high levels of energy, happiness, and the willingness to invest effort in one's work, and persistence even in the face of difficulties. Vigor is the antipode of fatigue in the burnout aspect (Schaufeli \& Salanova, 2007). Dedication refers to being strongly involved in one's work and followed by a sense of enthusiasm, inspiration, pride, and challenge. Dedication is the antipode of cynism (Schaufeli \& Salanova, 2007). Absorption is characterized by being fully concentrated and happily engrossed in one's work, whereby time passes quickly because one is drawn into the feeling of love for his job. Bakker \& Demerouti (2008) stated that there are two things effecting work engagement, which are organizational resources (job resources) and psychological resources (personal resources).

\section{Organizational Resources (Job Resources)}

In previous studies, work engagement was always associated with organizational resources such as skills, autonomy, and learning opportunity (Schaufeli \& Bakker, 2004b; Schaufeli \& Salanova, 2007). Organizational resources refers to the physical, social, or organizational resources that can reduce job demands relating to physiological and psychological functions in order to achieve a goal and to stimulate individual's growth, learning, and development (Schaufeli \& Bakker, 2004). Organizational resources are assumed to have intrinsic motivation and extrinsic motivation. Intrinsic motivation contributes to the worker's growth, learning, and development; while extrinsic motiva- 
tion acts as a helper in achieving goals (Schaufeli \& Bakker). Job resources also have an extrinsic motivational role, because a working environment that is full of resources can help the development of someone's willingness to dedicate efforts and skills to do his tasks (Meijmen \& Mulder, as cited in Bakker \& Demeriouti, 2008). This environment creates the opportunity for tasks to be done as well as the goals achievement (Bakker \& Demerouti, 2008).

The idea of a positive correlation between the role of motivation in job resources and work engagement was supported by some studies, and one of them is the study of Schaufeli \& Bakker (2004). They found a positive correlation between three job resources and work engagement (Vigor, Dedication, Absorption). The three job resources are task level or performance feedback, interpersonal level or support from colleagues, and organizational level or supervisory coaching. This study was conducted in four different samples of Dutch workers. Additionally, according to Hobfoll (cited in Bakker \& Demerouti 2008), job resources can become more important because they brought out someone's motivational potentials while dealing with high job demands (work load, emotional load, and mental load) until their goals are reached.

\section{Psychological Resources (Personal Resources)}

Personal resources are the aspects of the self that are generally associated with resilience and refer to the ability of an individual to control, which influence his success in the environment (Hobfoll, Johnson, Ennis, \& Jackson, as cited in Xanthopoulou, Bakker, Demerouti, \& Schaufeli, 2007). Xanthopoulou, Bakker, Demerouti, \& Schaufeli (2007) included three types of personal resources, which are self-efficacy, organizational-based self-esteem, and optimism. The three personal resources have been recognized by Hobfoll (cited in Xanthopoulo, Bakker, Demerouti, \& Schaufeli, 2007) as fundamental components of individuals' adaptation skills. According to Hobfoll et al. (cited in Bakker \& Demerouti, 2008) personal resources are defined as a positive self-evaluation that is associated with resilience and referred to individuals' ability to control, affect, and be successful in their environment. Positive self-evaluation is strongly associated with various aspects of work engagement (Xanthopoulou, Bakker, Demerouti, \& Schaufeli, 2007).

Bakker \& Demerouti (2008) stated that workers who are engaged have the tendency to believe that they will produce good experience in life (optimism) and they believe that they can fulfill needs and feel satisfied by taking up a role in an organization (organizational-based self-esteem). Bakker et al. (cited in Xanthopoulou, Bakker, Heuven, Demerouti, \& Schaufeli, 2008) found that workers who are engaged receive the highest score in personal resources. Personal resources consisted of optimism, self-efficacy, self-esteem, resilience, and various active ways. These factors help workers to control and impact their work environment as well as to achieve career success (Bakker \& Demerouti, 2008). The study conducted by Bakker \& Demerouti (2007) indicates that elementary, middle school, and high school teachers are mainly affected by job resources to face job demands. Job resources are specifically composed by social support, innovation, appreciation, and working climate or the situation inside the organization. From the two factors that can affect work-engagement, Bakker \& Demerouti (2007, 2008) made the JD-R theory (job demandresources) of work engagement (see Figure 1).

There are several factors included in the workengagement, including workload, emotional demands, emotional dissonance (Demerouti et al., as cited in Xanthopoulou, Bakker, \& Demerouti, \& Schaufeli, 2007), work pressure, physical demands (Demerouti et al., as cited in Bakker \& Demerouti, 2008).

Job demands have a role as the moderator between job resources or personal resources and work engagement. The higher the job demands given to workers, the more important the job resources because they can motivate workers (Bakker \& Demerouti, 2008). Motivated workers or work-engaged employees will create high levels of performance. As a result, workengaged employees who have high levels of performance will be able to create their own job resources.

\section{The Effects of Work Engagement}

Bakker and Demerouti (2008) described four reasons of why work-engaged employees show better performance than disengaged employees, which are:

1. Positive Emotions. Several studies indicate that employees who are engaged to their works often felt positive emotions (Schaufeli \& Vhan Rhenen, as cited in Bakker \& Demerouti, 2008). Happy people will be more sensitive to work opportunities, more open, more likely to help others, more confident and optimistic (Cropanzo and Wright, as cited in Bakker \& Demerouti, 2008). Positive emotions theory (Broaden $\&$ Bulid Theory) suggests that positive emotions consisted of happiness, interest, and contentment that dominate one's mind and built personal resour- 
ces from physical and intellectual resources as well as social and psychological resources (Fredrickson, as cited in Bakker \& Demerouti, 2008).

2. Good Health. The study explains that engagement has a positive correlation with health. This implicates a work performance that is far superior compared to someone who is not engaged in his work. Schaufeli, et al. (cited in Bakker \& Demerouti, 2008) mentioned that work-engaged employees have fewer psychosomatic disorders compared to disengaged workers. Demerouti et al. (cited in Bakker \& Demerouti, 2007) also found a negative correlation between work engagement, especially in energy aspect, and health disorders such as headache or chest pain. Shirom (cited in Bakker \& Demerouti, 2008) also argued that vigor is positively correlated with mental health and physical health.

3. Managing Personal Resources. One of the reasons of why engaged workers are more productive is probably because of their ability to empower their internal resources. Fredrickson (cited in Bakker \& Demerouti, 2008) supported this with the BroadenBuild theory which explains that the experience from positive emotions can build everlasting personal resources and triggers the increase of emotional wellbeing. Simultaneously, work engagement generates better personal resources (optimism, self-efficacy, organizational-based self-esteem), and more job resources (colleagues' social supports, autonomy, coaching, and reinforcement) (Bakker \& Demerouti, 2008).

4. Channelling Attachment to Others. In most organizations, performance is the result of the works of individuals in a team. Therefore, the channeling of work engagement can occur between team members to produce a better performance. The transmission of emotions can be interpreted as the transference of experience, both positive and negative experience from one person to another (Westman, as cited in Bakker \& Demerouti, 2008). Bakker et al. (cited in Bakker \& Demerouti, 2008) found that work engagement in a team is related with the work engagement of individual team members - including the aspects of vigor, dedication, and absorption.

Several researches show that work-engaged employees demonstrate better performance. Work engagement brings good effects or consequences for the organization or company, this is supported by a study conducted by Salanova, Agut, and Peiro (2005) in hotels and restaurants customer service which shows that high level of work engagement result in better work situations and customer satisfaction and more frequent visits. Another study related with work engagement was also done by Schaufeli to different subjects. Schaufeli et al. (2002a) conducted a study to Spanish, Portuguese, and Dutch students, the result indicates that engaged students will succeed in the final exam.

\section{Self-Efficacy}

Based on the Social Cognitive Theory (SCT), selfefficacy is defined as a belief in one's ability to organize, to execute, and also to produce courses of action to attain results (Bandura, as cited in Schaufeli \& Salanova, 2007). Bandura (Bandura \& Locke, 2003) explained that SCT is rooted from an agentic, in which people function in anticipative and purposive manners, and actively evaluate themselves as well as organizing their behavior and motivation. Furthermore, Bandura (1977) stated that self-efficacy enables a person to function through anticipatory, purposive, and self-regulatory mechanism in which people actively evaluate themselves and organize their behavior and motivation through cognitive, motivational, affective, and decision-making process. Another definition of self-efficacy is a capacity to develop self-ability to cope with a dynamic situation. Individuals with stagnant ability will not have a very strong belief about their capacity (Bandura \& Wood, 1989). Bandura limited the self-efficacy to be more specific as SSE (Specific Self-Efficacy) because it is based on the level and power of a person's dimension, as well as the conceptualization and learning.

Other scholars such as Judge et al (Judge, Kluger, Locke, \& Durham, 1998) defined General SelfEfficacy or GSE as an expectation of the ability that can raise motivation, cognition resources, and do a necessary action that are needed in life. GSE and SSE (Specific Self-Efficacy) both show individuals' belief in their ability to achieve their expectations, but they have different concepts related to the scope that are either general or specific (Eden, as cited in Imam, 2007) whereas the antecedent are the same; including actual experience, vicarious experience, verbal persuasion, psychological state (Bandura, 1997 in Chen, Gully, \& Eden, 2001). Even though they have different concepts and same antecedents, these things have received a lot of criticism from researchers (such as Bandura, 1997; Cervone, 1997; Statjkovic \& Luthans, as cited in Scherbaum, CohenCharash, \& Kern, 2006). A belief is the major basis of the appearance of an expected behavior in various kinds of demands in daily life. According to Shelton 
(Imam, 2007) the same antecedent of GSE and SSE actually give more impact to GSE. This is due to the emergence of GSE that exist throughout life as an accumulation of successes and failures of various tasks. The author used Bandura's perspective (Llorens, Salanova, Schaufeli, Bakker, 2007), which stated that self-efficacy is the belief in one's competence to organize and do an action from accepting the task until the desired result is obtained.

\section{The Understanding of Teachers' Self-Efficacy}

Bandura (Skaalvik \& Skaalvik, 2009) stated that based on the concept of self-efficacy, the understanding when specified to teachers' include teachers' ability to plan, organize, and execute what the neccesary to achieve educational purposes. Teachers' self-efficacy is defined as teachers' belief in their own ability to organize and to do what it takes in order to complete teachers' specific tasks successfully (TschannenMoran, Hoy \& Hoy, as cited in Shaukat \& Iqbal, 2012). Bandura (1977) explained that there are four selfefficacy resources, namely:

1. Performance Accomplishment. Performance accomplishment is a resource based on personal experience from the past. There are two things determining the impact of past experience to self-efficacy: success and failure. If a person experienced success, the expectation and self-efficacy would increase; in contrast, if a person experienced failure for several times, the expectation and self-efficacy would decrease.

2. Vicarious Experience. Vicarious experience is a resource derived from the modelling of another person, or in other words from a comparison to another observed individual. When the modelled individual achieves an accomplishment, we tend to think that we will be able to succeed just like the model. In contrast, when the model experiences failure, we will think that the same thing will happen to us.

3. Verbal Persuasion. Verbal persuasion is a source of self-confident and can be used at anytime by suggesting others. People who are given a positive suggestion will experience the rise of self confidence and be more realistic. If a person was given a suggestion and then was influenced to be successful, there is a chance that the person would be successful even though he had experienced failure in the past.

4. Emotional Arousal. This source of self-efficacy is influenced by the arousal of emotion that depended on a person's normative value as a reaction to a situation.

Aspects of self-efficacy. According to Woodruff
\& Cashman (1993) GSE (General Self-Efficacy) have three aspects, namely: (1) Initiative. Initiative is a desire to start a behavior or work. (2) Effort. Effort is an action displayed by someone with the intention to do and to complete a behavior. (3) Persistence. Persistence is someone's tenacity that appears when facing a serious problem.

Bandura's social cognitive theory (Woodruf \& Cashman, 1993) proposed there are three aspects of self-efficacy, including: (1) Magnitude, a belief in one's performance when facing increasing levels of difficulty in doing a task or a job. (2) Strength, an effort to organize one's behavior during a difficult situation. (3) Generality, which is related with how far a person believe in his own ability to face tasks and situation.

Skaalvik \& Skaalvik (2009) introduced six aspects of teachers' self-efficacy, namely:

1. Instruction. One of the important tasks of teachers is to explain the learning materials so that students can understand fundamental principles. This dimension focuses on teachers' effort to instruct students, to explain the learning materials, to give feedback on students' work, and to answer questions in order to increase students' understanding.

2. Adapting Education to Individual Students' Needs. Education should be adjusted to the needs of each student. The adaptation of eduation to students' individual needs is the key element in the movement towards inclusive education.

3. Motivate Students. Motivating students is another important task of teachers. It is also associated with and emphasized on the curiculum.

4. Keeping Discipline. The ability to organize and to discipline students is one of the aspects of teachers' self-efficacy.

5. Cooperate with Colleagues and Parents. In most schools, teachers work in a team and share responsibilities for a larger group of students. In addition, they are expected to cooperate with parents extensively. One important part is to share information on school tasks with parents, another is to make decisions with the parents.

6. Cope with Change. Every school can change every instruction in the classroom. Each teacher not only oversees 20 to 30 students in each class, but also a member of a teaching team. The competence to cope with ongoing change and new challenges is included in the dimension of teachers' self-efficacy.

The meaning of work. The meaning of work is defined as a subjective feeling created by someone towards his work (Pratt \& Ashforth, as cited in Wrzesniewski 
et al., 2003). Baumeister \& Vohs (Wrzesniewski, 2003) defined the meaning of work as a part of the area of positive psychology, positive meaning of work is defined as a relationship between two different things that creates a non-physical reality that is accessed by human. More specifically, meaning is a tool used by individuals to achieve stability in their lives (Baumeister \& Vohs, as cited in Wrzesniewski et al., 2003). Wrzesniewski, Dutton, \& Debebe (2003) defined the meaning of work as employees' understanding about what they have to do in the work place and the importance of the things they do.

The meaning of work as a calling. Bellah et al. (1985) explains the three dominant work orientations that reflect the work experience of employees in the United States. The three orientations are job, career, and calling. The employees who have the work orientation as a calling will regard work not for the financial award or progress, but as a fulfillment. In calling, work is related with a belief that work contributed in making the world a better place. Elangoven, Pinder, McLean (2010), define a calling as an action to achieve the aim of the finding of prosocial intentions that actualizes an individual who has the desire to do something, has the responsibilities that should be kept, and lives up to what should be done.

Wrzesniewski, McCauley, Rozin, and Schwartz (1997) defined the term as a person who is usually seen as socially valuable and involved in activities that are considered unimportant, but could actually find happiness from them. The term calling is originally used in a religious context, as a person who has the understanding that he is "called" morally and socially while working or doing his job (Weber, as cited in Wrzesniewski, McCauley, Rozin, \& Schwartz 1997). As science has developed, the term calling in religious context has lost its religious conotation and is now defined as an enjoyment and delight in the work of individual to make his work a better place (Wrzesniewski et al., as cited in Wrzesniewski, 2010).

In the definitions above, there is a compatibility with the study conducted by Elangoven et al. (2010) about the calling in organizational behavior, that produce three important elements, including the beliefs, attitudes, and values of a person that will bring out behavior. A calling has different specific meanings, direction, and significance for each individual, as well as making the world a better place for oneself and others. There are three origins for someone to identify the pattern of the meaning of work (Whitely, 1987), which are: (1) Biographical Variables (a. Personal characteristics; b. Home and community situations; c. Upbringing); (2) Work history, job, and organizational characteristics; (3) The present job (a. Job characteristics, income, and hours of work; b. Organizational characteristics).

According to Elangovan et al. (2010) there are four conditions that influence the meaning of work as a calling, which are: (1) An urge to find meaning in one's life. The motivation to find meaning in one's life, including work, is an important factor to start and organize, as well as to identify a calling. The urge arises because there is a dissatisfaction with current working conditions or living conditions, as a response to a significant event in life that changes a perspective; (2) Attentiveness. The second important factor to find and to identify a person's meaning of work as a calling is attention as part of individuals. Attention enables individuals to get a chance, modify when it is needed, or to change him/herself to be more meaningful. It can be concluded that a calling appears in many different forms and ways, but to maintain it, one has to be alert of the available possibilities; (3) Willingness to experiment with new paths. Another factor that plays an important role in individuals' abilities to find their calling is the willingness to experiment with new paths. Novak (Elangovan et al, 2010) stated that the existence of willingness is one of the requirements to find the calling. Weiss et al. (Elangovan et al, 2010) emphasized the importance to conduct experiments and to persist in an effort. These two things are important to narrow the choices of calling; (4) Growing understanding of the self. The understanding of the self is a factor needed to identify a calling. As explained before, self-identity and self-development are the sources of calling. Pratt and Ashforth (Elangovan et al, 2010) observed that calling involved role, identity, and meaningfulness. The definition of ideal convergent calling has to show in actual that one of the main requirement that must be considered is the real individual self, and to have a good understanding of an ideal self.

\section{The Effects of the Meaning of Work as a Calling}

Wrzesniewski et al. (2003) stated that work orientation as a calling has several impacts on individual, working group, and also organization. The three impacts could be explained as follow:

Individual impact. The orientation of work as a calling leads to different working behavior, attitude, and emotional effects to people who interpret their work as career and job. Individuals who interpret their 
work as a calling will provide more time, have better work results, and are more satisfied with their life and work environment compared to the people who interpret their work as career and job.

Work groups impact. The orientation of work have impacts on work groups and organization. The orientation of work impact on work groups are strong identification within groups, the decerase in the number of conflicts, the increase in commitment and trust to the management and the team, the increase of health in group process, and the presence of satisfaction towards colleagues and the job itself.

Organizational impact. The study by Wrzesniewski and Landman (Wrzesniewski et al., 2003) on nurses shows that nurses who interpreted their work as a calling had more optimal performance and felt satisfied with their works. Another evidence shows a strong correlation between work satisfaction and the meaning of work as a calling. Because of that, there exists an indirect correlation between the meaning of work as a calling and high work satisfaction, and then a correlation between high work satisfaction and performance.

\section{The Correlation Between Teachers' Self- Efficacy and Work Engagement}

Teachers are professional educators responsible for planning the learning process, perform coaching and training, and conduct researches and community service. This is particularly the case for educators at the university level (Undang-Undang Sistem Pendidikan, 2003). Teachers' role are not only to educate, to teach, and to guide; but teachers are also required to display behaviors in accordance with the norms of community, nation, and state; as well as doing administrative work properly and systematically. These make teachers the spearhead in the education field.

These regulated roles have not taken place in Indonesia and the nation's educational quality is poor. The low quality of education in Indonesia is caused partly by the vast amount of teachers who work casually (PGRI Akui Ada, 2010). The characteristics of teachers who work not in accordance with the written constitution are: being unprepared during class, coming late to class, and feeling unmotivated while teaching. The characteristics reported by Kompas (PGRI Akui Ada, 2010) demonstrate the forms of gap between teachers and their work.

Someone who has experienced a gap or unhappiness in employment has less engagement to work. As stated above, three things that characterize work enga- gement are vigor, dedication, and absorption. This particular entanglement is defined as the concept of work motivation. When a person is engaged to his occupation, he will feel challenged and this will create the urge to achieve the goal of his occupation, which is success.

Engagement towards work is influenced by two factors; one of them is psychological resources (Demerouti et al., as cited in Bakker and Demerouti, 2008). Psychological resources consist of optimism, confidence, selfesteem, and joy (resilience). Someone who is able to organize psychological resources will then be able to control and influence his work environment (Bakker $\&$ Demerouti, 2008).

Self-confidence, which is based on SCT, is a belief in the ability to organize and execute as well as produce an action that will have a result (Bandura, as cited in Schaufeli \& Salanova, 2007). Self-esteem has different concepts that are related in both general and specific scope (Eden, as cited in Imam, 2007). Teachers who have high selfconfidence are characterized by their provision of easily understandable explanations and in accordance with the students' needs, ability to motivate students to be more diligent and active in school, maintenance of discipline in various situations, in the classroom and outside. Also able to collaborate with colleagues and parents whose aims are to be able to understand better the character of students, able to overcome the changes that occur in a school environment. Based on the characteristics of teachers with high self-confidence thus those particular teachers are increasingly tied to their job, and are characterized by working with more spirit, dedicating her/himself to the job, and appreciating the work. These characters indicate a teacher who has a high work commitment.

Hypothesis 1: There is a correlation between teacher's confidence and teacher's work engagement (see Figure 2)

\section{The Relationship between the Meaning of Work as a Calling and Work Commitment}

Teachers act as primary movers in the occurrence of teaching and learning process. The process of teaching and learning is a process of direct interaction between teachers and students. In a week, teachers are required to teach for 24 hours, divided into eight hours in a day and 90 minutes to 120 minutes for each subject. This certainly affects the motivation of teachers to teach in accordance with the rules set 


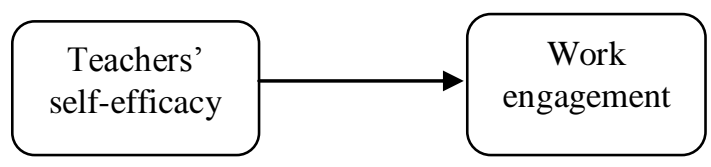

Figure 2. The correlation between teachers' confidence and teachers' engagement towards work.

for them. However, based on a report by the Indonesian Association of Teachers (PGRI Akui Ada, 2010), many teachers do not meet the requirement of 24 hours per week. This is due to the lack of motivation of teachers to teach and the lack of available facilities.

Money is also a major problem for teachers. Many teachers resign and look for better-paid jobs (PGRI Akui Ada, 2010). Financial problems can also trigger teachers to plagiarize in scientific journals (Guru kok Plagiat, 2013). The dissemination of articles in scientific journals has been required by the Department of Education in April 2013 as a condition of salary promotion, greater benefits, and prestige (Guru Naik Pangkat, 2013). Plagiarism in scientific work is caused by teacher-oriented financial gain and positions.

Wrzesniewski et al. (2003) stated that a worker is an active interpreter of meaning. The construction of meaning is done through interpretation and reflection. In accordance with Aktouf's research (Heuvel et al, 2009), both studies show that the absence of meaning in a work (lack of meaning) leads to a lack of engagement (disengagement) or alienation.

A person feels the meaning of his job will bring a sense of personal devotion and a strong commitment. A strong commitment is an aspect of job dedication, commitment, offset by the enthusiasm, inspiration, pride and challenge. The above explanation is also supported by a research that shows how individuals derive meaning from their job has a deeper appreciation for his job, such as pleasure and satisfaction when spending a lot of time to work (Wrzesniewski, McCauley, Rozin, \& Schwartz, 1997). These conditions indicate the existence of spirit and enthusiasm that characterize aspects of the work that is the spirit of commitment and dedication.

Based on the description above it can be concluded that individuals who consider their jobs as a calling will be engaged to the job, as well as the need to complete a self-confidence and skills to face the task work expectation.

Hypothesis 2: There is a correlation between teachers' work as a calling and the attachment of work (see Figure 3).

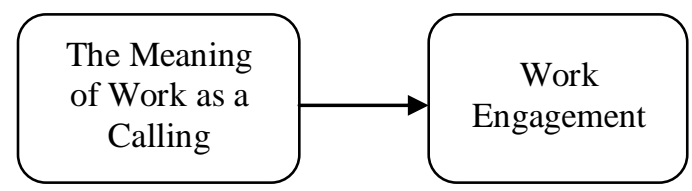

Figure 3. The correlation between work significance as a calling and attachment.

\section{Method}

\section{Research Variables}

Determinant variable: Work engagement. The operational definition of work engagement is positive, satisfying, and work-related state of mind; characterized by vigor, dedication, and absorption. The level of work engagement in this study was measured by using the scale of work engagement. The higher the score of work engagement, the higher the level of work engagement; in contrast, the lower the score of work engagement, the lower the score of work engagement. The scale was measured by 17 items in the form of questions that were arranged by using Likert's scale, with five alternatives of answer. Each of the questions had five options of answer, namely always happens $(\mathrm{AH})$, often happens $(\mathrm{OH})$, sometimes happens $(\mathrm{SH})$, rarely happens $(\mathrm{RH})$, and never happened (NH). The scale of work engagement was a translated scale that was adapted from the UWES (Utrecht Work Engagement Scale).

Predictor variable: Teachers' self-efficacy. The operational definition of self-efficacy is belief in an individual's capabilities to organize and execute the courses of action required to manage prospective situations (Bandura, 1995) in order to produce positive results with the willingness to initiate and to put out an effort and to persevere in solving serious problems. Teachers' self efficacy is defined as teachers' belief in their ability to plan, to organize, and to perform the things needed in order to achieve desired results. The level of teachers' self-efficacy was measured by using the NTSES (Norwegian Teacher SelfEfficacy Scale). This scale consisted of 38 items in the form of questions. It was arranged using Likert's scale with five alternatives of answer. Each of the statement had five options of answer, namely always happens $(\mathrm{AH})$, often happens $(\mathrm{OH})$, sometimes happens $(\mathrm{SH})$, rarely happens $(\mathrm{RH})$, and never happened $(\mathrm{NH})$. The scale of work engagement was a translated scale adapted from the NTSES (Norwegian Teacher Self-Efficacy Scale). 
Predictor variable: The meaning of work as a call-ing. The definition of the meaning of work as a calling is a process that does not interpret the work based on financial gain or other benefits but for the fulfillment derived from the work itself (Dik \& Steger, 2006) that individual would be more engaged to his work because the work became a part of his life. The level of work engagement was measured by using the Work-Orientations Measurement and arranged by using Likert's scale. The scale was adapted from the Work Orientation Measurement (Wrzesniewski, McCauley, Rozin, \& Schwartz, 1997) that consisted of 18 items which measured the meaning of work as a calling, career, and job using Likert's scale that had five alternatives of answer, namely always happens $(\mathrm{AH})$, often happens $(\mathrm{OH})$, sometimes happens $(\mathrm{SH})$, rarely happens (RH), and never happened (NH). This scale had 18 items, but only eight items were used since the variable of the meaning of work was focused on the calling category. The blue print of the research instrument scales is shown in Table 2 .

\section{Population and Sampling Technique}

In this study, researches used the population of teachers from three different private schools in Surabaya namely High School X, High School Y, and High School Z. The total subjects were 87 teachers. The sampling technique used was convenience sampling. The sampling was done by the schools by choosing the teachers who taught one or two subjects and were responsible for the school management. The consideration was that teachers who taught one or two subjects would be more engaged to their work because of the job description and their responsibility on the management. The total research subjects were
112 people. The sampling was done based on the information given from the vice principle and public relation of each school, claiming that there were several teachers who lacked in motiva-tion to teach.

\section{Technique of Data Collection and Analisis}

In this study, the data was measured using a scale that consisted of several parts, which were: the first part in the form of a petition sheet, the second part in the form of an open-ended questionnaire that revealed the identity of the subject, the third part in the form of a work engagement scale, the fourth part in the form of self-efficacy scale, and the fifth part in the form of the meaning of work as a calling. This study was classified as a quantitative study: a correlation test by the use of survey technique. The data in this study was analyzed using statistic analysis, in which the calculation was carried out by the IBM SPSS 19 statistical program. There were several requirements to be fulfilled in order to perform data analysis in the hypothesis testing, namely: validity test, reliability test, and assumption test.

\section{Instrument Test}

Validity Test. The validity used in this study was the content validity, or more specifically the logical validity. The aim of the validity test was to make sure that the statements used actually measured the operational variable. The validity of the scales of work engagement, teachers' self-efficacy, and the meaning of work as a calling were determined by looking at aspects and items that were organized based on the theory according to expert judgment matter (Straub, Straub et al., as cited in Azwar, 2012).

Table 2

Specification of Research Instrument Scales

\begin{tabular}{lclcc}
\hline \multicolumn{1}{c}{ Instrument } & No & \multicolumn{1}{c}{ Aspect } & Item & Total \\
\hline Utrecth Work & 1 & Vigor & $1,4,8,12,15,17$ & 6 \\
Engagement Scale & 2 & Dedication & $2,5,7,10,13$ & 5 \\
& 3 & Absorption & $3,6,9,11,14,16$ & 6 \\
Norwegian Teacher Self- & 1 & Teaching & $1,8,12,16,25,28,31$ & $\mathbf{1 7}$ \\
Efficacy Scale & 2 & Adaptating Instructions for Individual Needs & $5,11,18,23,26,33$ & 6 \\
& 3 & Motivating Students & $2,10,15,21,36,38$ & 6 \\
& 4 & Maintaining Discipline & $6,9,14,19,29,30,32$ & 7 \\
& 5 & Working with Colleagues and Parents & $3,7,13,22,27,35$ & 6 \\
& 6 & Coping with Changes & $4,17,20,24,34,37$ & 6 \\
Scale of the Meaning of & 1 & Calling & & $\mathbf{3 8}$ \\
Work as a Calling & & & $1,2,5,6,7,12,13,14$ & $\mathbf{8}$ \\
\hline
\end{tabular}


Table 3

Distribution of Research Subject Demographic Data Frequency

\begin{tabular}{|c|c|c|c|}
\hline & Demographic Data & Frequency & Percentage \\
\hline \multirow{4}{*}{ Sex } & Male & 34 & $39.1 \%$ \\
\hline & Female & 47 & $54 \%$ \\
\hline & Unidentified & 6 & $6.9 \%$ \\
\hline & & 87 & $100 \%$ \\
\hline \multirow{6}{*}{ Age } & $15-24$ & 6 & $6.9 \%$ \\
\hline & $25-44$ & 57 & $65.5 \%$ \\
\hline & $45-65$ & 22 & $25.3 \%$ \\
\hline & $>65$ & 1 & $1.1 \%$ \\
\hline & Unidentified & 1 & $1.1 \%$ \\
\hline & & 87 & $100 \%$ \\
\hline \multirow{5}{*}{ Level of Education } & Master & 11 & $12.6 \%$ \\
\hline & Bachelor & 70 & $80.5 \%$ \\
\hline & High School & 5 & $5.7 \%$ \\
\hline & Unidentified & 1 & $1.1 \%$ \\
\hline & & 87 & $100 \%$ \\
\hline \multirow{7}{*}{ Length of Employment } & $0-10$ years & 53 & $60.9 \%$ \\
\hline & $11-21$ years & 18 & $20.7 \%$ \\
\hline & 22-32 years & 11 & $12.6 \%$ \\
\hline & 33-43 years & 1 & $1.1 \%$ \\
\hline & 44-54 years & 1 & $1.1 \%$ \\
\hline & Unidentified & 3 & $3.4 \%$ \\
\hline & & 87 & $100 \%$ \\
\hline
\end{tabular}

Reliability Test. It was done in order to show the scale consistency in measuring variable. The reliability test was done by using the coefficient of alpha cronbach.

Assumption Test. The test was done in order to find out the normality of spread distribution, and whether the dissemination of data as the result of scale collection had followed the normal distribution. The requirement was $p<.05$.

Hypothesis Test. Another statistical technique used was the Non-Parametric test. The non-parametric test was done using Spearman's method. The test was conducted because the distribution of subjects' data was not normal. The requirement to be classified as correlated was $p<.05$.

\section{Results}

The study was conducted at three private schools in Surabaya through a permission request by phone as well as direct visits in which permission letter and research proposal were submitted in order to obtain cooperation from schools. The data collection was conducted by distributing questionnaires. The author had also asked for permission to conduct an initial survey by interviewing and providing questionnaires for schools' public relation or vice principles. Schools' public relation or vice principles gave direct permissions, so that the author did not need to make an official letter for the school. The author asked for the schools' profiles, list of teachers' names, and the structure of organization of each school (see Table 3).

This study involved 87 teachers, with a larger proportion of female (54\%) compared to male $(39.1 \%)$. Most of the subjects were 25-44 years old (65.5\%) and 45-65 years $(25.3 \%)$. The number of teachers who worked for less than 10 years were $53(60.9 \%)$ and the number of teachers who worked for more than 20 years were 13 (14.8\%). This study's demographic data was similar to the research of Simbula, Guglielmi, \& Schaufeli (2011) in having teachers as the research subjects, the dominance of female subjects (90\%) 
Table 4

Reliability Test Result

\begin{tabular}{llcc}
\hline No & \multicolumn{1}{c}{ Variable } & $\begin{array}{c}\text { Alpha } \\
\text { Cronbach } \\
\text { Coefficient }\end{array}$ & Status \\
\hline 1 & Work Engagement & .917 & Reliable \\
2 & Teachers' Self- & .901 & Reliable \\
& Efficacy & .757 & Reliable \\
3 & The Meaning of & & \\
& Work as a Calling & & \\
\hline
\end{tabular}

Table 5

Normality Test

\begin{tabular}{llcl}
\hline No & \multicolumn{1}{c}{ Variable } & $\begin{array}{c}p \\
\text { Kolmogorov- } \\
\text { Smirnov }\end{array}$ & Status \\
\hline 1 & Work & .026 & Not \\
& $\begin{array}{l}\text { Engagement } \\
\text { Teachers' Self- }\end{array}$ & .730 & Normal \\
& $\begin{array}{l}\text { Efficacy } \\
\text { The Meaning of } \\
\text { Work as a Calling }\end{array}$ & .790 & Normal \\
& & & \\
\hline
\end{tabular}

Table 6

Hypothesis Test Result

\begin{tabular}{cccc}
\hline \multicolumn{2}{c}{ Variable } & $r$ & $p$ \\
\hline $\begin{array}{c}\text { Work } \\
\text { Engagement }\end{array}$ & $\begin{array}{c}\text { Teachers' Self } \\
\text { Efficacy }\end{array}$ & .508 & $<.05$ \\
& $\begin{array}{c}\text { The Meaning of } \\
\text { Work as a Calling }\end{array}$ & .612 & $<.05$ \\
\hline
\end{tabular}

when compared to male (10\%), most of subjects' age were more than 50 years $(33 \%)$, and $51 \%$ of the sub-jects had worked for more than 20 years. Based on the demographic data, the study's result was similar to the research of Simbula, Guglielmi, \& Schaufeli (2011), in which teachers' self-efficacy was positively correlated with work engagement. This indicates that teachers' self-efficacy was related to work engagement.

Validity Test. The validity used in this study was content validity using the logical validity. Logical validity is a comon sense decision regarding the item's relevance with the purpose of measuring a scale based on the assessment of the writer and expert judgment (Straub; Straub et al., as cited in Azwar, 2012). The logical validity was done by understanding the theory used, and then observing the aspects that would be broken down into several items by using logical thinking or author's assessment.

Reliability Test. Table 4 reveals that the value of alpha Cronbach of all variables are included in the category of reliable $(p>.60)$. Work engagement shows the highest value of reliability which is .917 . The variable the meaning of work as a calling also shows a high reliability value which is .707 . The variable teachers' self-efficacy shows the lowest reliability value, but is still regarded as reliable at .685.

Assumption Test. Table 5 reveals that Work Engagement has the value $=.026(p<.05)$, this indicates that the data does not conform to the normal spread. The variable of Teachers' Self Efficacy and The Meaning of Work as a Calling have a similar and high in the probability value; in which the probability value of the variable of Teachers' Self Efficacy = $.790(p>.05)$. Both variables show that the field data conforms to the normal spread of data. In conclusion, the determinant variable, which is Work Engagement, is not normally distributed; while all of the predictor variables are normally distributed. The next test to be conducted was non-parametric statistic test.

Table 6 reveals that the variables of Teachers' Self-Efficacy and The Meaning of Work as a Calling have a correlation coefficient $(r)=.508 ; p<.05$. This means that self-efficacy has a significant correlation with work engagement. Table 6 also shows that the meaning of work as a calling and work engagement have a correlation coefficient $(r)=.612 ; p<.05$. This means that the meaning of work as a calling has a significant correlation with work engagement.

\section{Categorical Determination of Research Variables}

The variables used in this study are described as follows:

The variable of work engagement. Subject classication based on each variable is classified using the calculation formula of Ideal Mean and Ideal Standard Deviation, which are:

$$
\begin{aligned}
& \text { Mean } \text { Ideal }=\frac{(\text { Jav } \times N a t)+(J a v \times}{2} \\
& \mathrm{SD}_{\text {Ideal }}=\frac{(\text { Jav } \times N a t)-(\text { Jav } \times N a r)}{6} \\
& \text { Notes. } \\
& \text { Jav : Total number of valid items } \\
& \text { Nat: Highest value of items } \\
& \text { Nar: Lowest value of items }
\end{aligned}
$$

Work engagement is classified into five categories, which are:

Very high : $\mathrm{X} \geq($ Ideal Mean $+1,8$ Ideal $S D)$

High : (Ideal Mean $+0.6 S D$ ideal) $\leq \mathrm{X}<$ (Ideal Mean + 1.8 Ideal SD) 
Moderate : (Ideal Mean $-0.6 S D$ ideal) $\leq \mathrm{X}<$ (Ideal Mean + 0.6 Ideal SD)

Low : (Ideal Mean $-1.8 S D$ ideal $) \leq \mathrm{X}<($ Ideal Mean -0.6 Ideal $S D$ )

Very Low : $\mathrm{X} \leq$ (Ideal Mean $-1.8 S D$ ideal $)$

The result is shown on the Table 7. Table 7 shows that the majority of teachers (85 teachers/97.7\%) are classified in the high level category of work engagement. There are also two teachers (2.3\%) who are classified in the moderate level of work engagement.

The variable of teachers' self-efficacy. The classification of subjects based on each category of teachers' self-efficacy is done by using the calculation formula of Ideal Mean and Ideal Standard Deviation. The result is shown in the Table 8 .

Table 8 reveals that most of the teachers are classified in the high category on teachers' self-efficacy with the number of 49 people $(56.3 \%)$. For the rest, 38 people are classified in the moderate category of teachers' self-efficacy with the percentage of $43.7 \%$.

The variable of the meaning of work as a calling. There are three categories of the meaning of work for the subjects, namely: calling, career, and job. The classification of calling is done by using the calculation formula of Ideal Mean and Ideal Standard Deviation. The obtained result is displayed on Table 9.

Table 9 shows that most teachers in the calling category are classified in the high group with the number of 71 people and percentage of $81.6 \%$. There are 14 teachers classified as moderate $(16.27 \%)$ and two $(2.3 \%)$ are classified as low.

\section{Cross Tabulation}

The data analysis was completed by a cross tabulation between determinant variable and predictor variables, and also the variable of work engagement and demographic data.

Table 7

Frequency Distribution of Work Engagement

\begin{tabular}{lcccc}
\hline & Category & Value Intervention & Frequency & Percentage \\
\hline Very High & $\mathrm{X} \geq 71.40$ & 29 & $33.3 \%$ \\
High & $57.80 \leq \mathrm{X}<71.40$ & 56 & $64.4 \%$ \\
Moderate & & $44.20 \leq \mathrm{X}<57.80$ & 2 & $2.3 \%$ \\
Low & $30.60 \leq \mathrm{X}<44.20$ & 0 & $0 \%$ \\
Very Low & & $\mathrm{X} \leq 30.60$ & 0 & $0 \%$ \\
& & & 87 & $100 \%$ \\
\hline
\end{tabular}

Table 8

Frequency Distribution of Teachers' Self-Efficacy

\begin{tabular}{lcccc}
\hline & Category & Value Intervention & Frequency & Percentage \\
\hline Very High & $\mathrm{X} \geq 159.60$ & 0 & $0 \%$ \\
High & $129.20 \leq \mathrm{X}<159.60$ & 49 & $56.3 \%$ \\
Moderate & $98.80 \leq \mathrm{X}<129.20$ & 38 & $43.7 \%$ \\
Low & $68.40 \leq \mathrm{X}<98.80$ & 0 & $0 \%$ \\
Very Low & $\mathrm{X} \leq 68.40$ & 0 & $0 \%$ \\
& & & 87 & $100 \%$ \\
\hline
\end{tabular}

Table 9

Frequency Distribution of the Meaning of Work as a Calling

\begin{tabular}{lcccc}
\hline & Category & Value Intervention & Frequency & Percentage \\
\hline Very High & $\mathrm{X} \geq 33.60$ & 18 & $20.7 \%$ \\
High & $27.20 \leq \mathrm{X}<33.60$ & 53 & $60.9 \%$ \\
Moderate & $20.80 \leq \mathrm{X}<27.20$ & 14 & $16.2 \%$ \\
Low & $14.40 \leq \mathrm{X}<20.80$ & 2 & $2.3 \%$ \\
Very Low & & $\mathrm{X} \leq 14.40$ & 0 & $0 \%$ \\
& & & 87 & $100 \%$ \\
\hline
\end{tabular}

Note. $\quad M_{\text {ideal }}=24.00 ; S D_{\text {ideal }}=5.33$ 
Table 10

Cross Tabulation Between Work Engagement and Teachers' Self-Efficacy

\begin{tabular}{|c|c|c|c|c|c|c|c|c|c|c|c|c|}
\hline \multirow{3}{*}{$\begin{array}{c}\text { Teachers' Self- } \\
\text { Efficacy }\end{array}$} & \multicolumn{10}{|c|}{ Work Engagement } & \multirow{2}{*}{\multicolumn{2}{|c|}{ Total }} \\
\hline & \multicolumn{2}{|c|}{ Very High } & \multicolumn{2}{|c|}{ High } & \multicolumn{2}{|c|}{ Moderate } & \multicolumn{2}{|c|}{ Low } & \multicolumn{2}{|c|}{ Very Low } & & \\
\hline & $f$ & $\%$ & $f$ & $\%$ & $f$ & $\%$ & $f$ & $\%$ & $f$ & $\%$ & $f$ & $\%$ \\
\hline Very High & 0 & 0 & 0 & 0 & 0 & 0 & 0 & 0 & 0 & 0 & 0 & 0 \\
\hline High & 3 & 3.4 & 0 & 0 & 0 & 0 & 0 & 0 & 0 & 0 & 3 & 3.4 \\
\hline Moderate & 23 & 26.4 & 38 & 43.7 & 0 & 0 & 0 & 0 & 0 & 0 & 61 & 70.1 \\
\hline Low & 3 & 3.4 & 18 & 20.7 & 2 & 2.3 & 0 & 0 & 0 & 0 & 23 & 26.4 \\
\hline Very Low & 0 & 0 & 0 & 0 & 0 & 0 & 0 & 0 & 0 & 0 & 0 & 0 \\
\hline Total & 29 & 33.3 & 56 & 64.4 & 2 & 2.3 & 0 & 0 & 0 & 0 & 87 & 100 \\
\hline
\end{tabular}

Table 11

Cross Tabulation Between Work Engagement and The Meaning of Work as a Calling

\begin{tabular}{|c|c|c|c|c|c|c|c|c|c|c|c|c|}
\hline \multirow{3}{*}{$\begin{array}{l}\text { The Meaning of } \\
\text { Work as a Calling }\end{array}$} & \multicolumn{10}{|c|}{ Work Engagement } & \multirow{2}{*}{\multicolumn{2}{|c|}{ Total }} \\
\hline & \multicolumn{2}{|c|}{ Very High } & \multicolumn{2}{|c|}{ High } & \multicolumn{2}{|c|}{ Moderate } & \multicolumn{2}{|c|}{ Low } & \multicolumn{2}{|c|}{ Very Low } & & \\
\hline & $F$ & $\%$ & $F$ & $\%$ & $f$ & $\%$ & $f$ & $\%$ & $f$ & $\%$ & $f$ & $\%$ \\
\hline Very High & 0 & 0 & 0 & 0 & 0 & 0 & 0 & 0 & 0 & 0 & 0 & 0 \\
\hline High & 9 & 10.3 & 4 & 4.6 & 0 & 0 & 0 & 0 & 0 & 0 & 13 & 14.9 \\
\hline Moderate & 19 & 21.8 & 45 & 51.7 & 0 & 0 & 0 & 0 & 0 & 0 & 64 & 73.6 \\
\hline Low & 1 & 1.1 & 7 & 8.0 & 2 & 2.3 & 0 & 0 & 0 & 0 & 10 & 11.5 \\
\hline Very Low & 0 & 0 & 0 & 0 & 0 & 0 & 0 & 0 & 0 & 0 & 0 & 0 \\
\hline Total & 29 & 33.3 & 56 & 64.4 & 2 & 2.3 & 0 & 0 & 0 & 0 & 87 & 100 \\
\hline
\end{tabular}

Table 12

Cross Tabulation Between Work Engagement and Research Samples'Demographic Data

\begin{tabular}{|c|c|c|c|c|c|c|c|c|c|c|c|c|c|}
\hline \multirow{3}{*}{\multicolumn{2}{|c|}{ Demographic Data }} & \multicolumn{12}{|c|}{ Work Engagement } \\
\hline & & \multicolumn{2}{|c|}{ Very High } & \multicolumn{2}{|c|}{ High } & \multicolumn{2}{|c|}{ Average } & \multicolumn{2}{|c|}{ Low } & \multicolumn{2}{|c|}{ Very Low } & \multicolumn{2}{|c|}{ Total } \\
\hline & & $f$ & $\%$ & $f$ & $\%$ & $f$ & $\%$ & $f$ & $\%$ & $f$ & $\%$ & $f$ & $\%$ \\
\hline \multirow[t]{5}{*}{ Age } & Unidentified & 1 & 100.0 & 0 & 0 & 0 & 0 & 0 & 0 & 0 & 0 & 1 & 100.0 \\
\hline & $15-24$ years old & 0 & 0 & 6 & 100.0 & 0 & 0 & 0 & 0 & 0 & 0 & 6 & 100.0 \\
\hline & $25-44$ years old & 18 & 31.6 & 37 & 64.9 & 2 & 3.5 & 0 & 0 & 0 & 0 & 57 & 100.0 \\
\hline & 45-65 years old & 9 & 59.1 & 13 & 40.9 & 0 & 0 & 0 & 0 & 0 & 0 & 22 & 100.0 \\
\hline & $>65$ years old & 1 & 100.0 & 0 & 0 & 0 & 0 & 0 & 0 & 0 & 0 & 1 & 100.0 \\
\hline \multirow[t]{3}{*}{ Sex } & Unidentified & 3 & 50.0 & 3 & 50.0 & 0 & 0 & 0 & 0 & 0 & 0 & 6 & 100.0 \\
\hline & Male & 13 & 38.2 & 20 & 58.8 & 1 & 2.9 & 0 & 0 & 0 & 0 & 34 & 100.0 \\
\hline & Female & 13 & 27.7 & 33 & 70.2 & 1 & 2.1 & 0 & 0 & 0 & 0 & 47 & 100.0 \\
\hline Level of & Unidentified & 1 & 100.0 & 0 & 0 & 0 & 0 & 0 & 0 & 0 & 0 & 1 & 100.0 \\
\hline \multirow[t]{3}{*}{ Education } & High School & 1 & 20.0 & 4 & 80.0 & 0 & 0 & 0 & 0 & 0 & 0 & 5 & 100.0 \\
\hline & Bachelor & 22 & 31.4 & 47 & 67.1 & 1 & 1.4 & 0 & 0 & 0 & 0 & 70 & 100.0 \\
\hline & Master & 5 & 45.5 & 5 & 45.5 & 1 & 9.1 & 0 & 0 & 0 & 0 & 11 & 100.0 \\
\hline Length of & Unidentified & 1 & 33.3 & 2 & 66.7 & 0 & 0 & 0 & 0 & 0 & 0 & 3 & 100.0 \\
\hline \multirow[t]{5}{*}{ Work } & $0-10$ years & 16 & 30.2 & 35 & 66.0 & 2 & 3.8 & 0 & 0 & 0 & 0 & 53 & 100.0 \\
\hline & $11-21$ years & 6 & 33.3 & 12 & 66.7 & 0 & 0 & 0 & 0 & 0 & 0 & 18 & 100.0 \\
\hline & $22-32$ years & 4 & 36.4 & 7 & 63.6 & 0 & 0 & 0 & 0 & 0 & 0 & 11 & 100.0 \\
\hline & $33-43$ years & 1 & 100.0 & 0 & 0 & 0 & 0 & 0 & 0 & 0 & 0 & 1 & 100.0 \\
\hline & $44-54$ years & 1 & 100.0 & 0 & 0 & 0 & 0 & 0 & 0 & 0 & 0 & 1 & 100.0 \\
\hline
\end{tabular}

Table 10 reveals that most subjects have high level of work engagements with moderate level of teachers' self-efficacy $43.7 \%$ ( 38 people). There are 23 teachers who have very high level of self-efficacy and very high level of work engagement (26.4\%). Based on Table 11 reveals that most subjects have high level of work engagement and moderate level of the meaning of work as a calling $51.7 \%$ (45 people). There are also 
Table 13

Difference Testing Result of Work Engagement between Schools

\begin{tabular}{cccc}
\hline Schools & Means Difference & $p$ & Status \\
\hline High School X - High School Y & 3.75 & & \\
High School X - High School Z & 6.27 & .647 & No Difference \\
High School Y - High School Z & 2.52 & & \\
\hline
\end{tabular}

Table 14

Difference Testing Result of Teachers' Self-Efficacy between Schools

\begin{tabular}{lccc}
\hline \multicolumn{1}{c}{ Schools } & Means & $p$ & Status \\
\hline High School Y & 106.5357 & & \\
High School Z & 105.3333 & .647 & No Difference \\
High School X & 104.8696 & & \\
\hline
\end{tabular}

Table 15

Mean Difference of Teachers' Self Efficacy between Schools

\begin{tabular}{cccc}
\hline Schools & Means Difference & $p$ & Status \\
\hline High School X - High School Y & -1.66615 & .608 & \\
High School X - High School Z & -0.46377 & .880 & No Difference \\
High School Y - High School Z & 1.20238 & .679 & \\
\hline
\end{tabular}

Table 16

Difference Testing Result of the Meaning of Work as a Calling between Schools

\begin{tabular}{lccc}
\hline \multicolumn{1}{c}{ Schools } & Means & $p$ & Status \\
\hline High School Z & 24.4722 & & \\
High School X & 24.1739 & .563 & No Difference \\
High School Z & 23.5714 & & \\
\hline
\end{tabular}

Table 17

Mean Differences of the Meaning of Work as a Calling between Schools

\begin{tabular}{rcccc}
\hline Schools & Mean Differences & $p$ & Status \\
\hline High School X - High & School Y & .60248 & 608 & \\
High School X - High & School Z & -.29831 & .880 & No Difference \\
High School Y - High & School Z & -.90079 & .679 & \\
\hline
\end{tabular}

19 teachers $(21.8 \%)$ who regard their work as a calling with very high level of work engagement. Table 12 reveals that most of the teachers are classified into the age range of 25-44 years with the total of 57 people and the percentage of $64.9 \%$ and have high level of work engagement. Another 18 people are classified as having very high level of work engagement with the percentage of $31.6 \%$. A small portion of the samples is distributed into the other age groups. Based on the sex distribution; most of the teachers are female with the number of 47 people, the total of male teachers are 34 people, and 6 teachers did not specify their gender. There are 33 female teachers $(70.2 \%)$ who have high level of work engagement, some are distributed in the very high level of work engagement. B ased on the level of education, most of the teachers (70) were graduated from university. There were 47 of them $(47.1 \%)$ with a high level of work engagement and 22 of them (31.4) are classified in the very high level of work engagement. Based on the length of work, it can be seen that most of the teachers were classified within the range of $0-10$ years with the number of 53 people $(66 \%)$ and these teachers have high level of work engagement. There are 18 teachers who have worked for 11-21 years and most of them $(66.7 \%)$ are classified in the high level of work engagement.

\section{Additional Analysis}

Table 13 shows that based on the difference testing of work-engagement variable, there is no difference between the three schools. High School X and High School Y are classified in the mean range of $47.80-$ 44.05 with the $p>.05$. High School $\mathrm{X}$ and High 


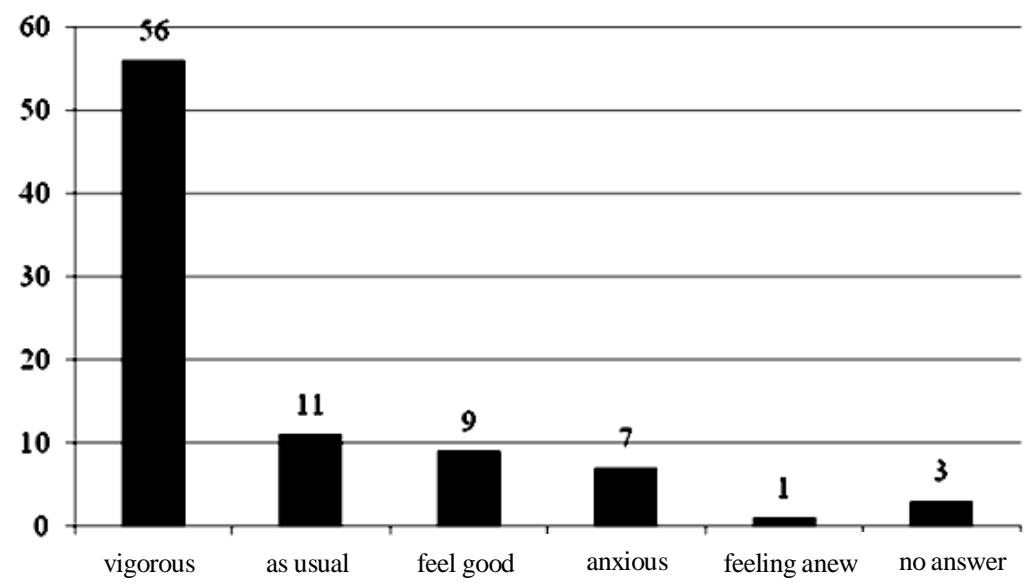

Figure 4. Graphic of teachers' feeling/emotion when leaving for work.

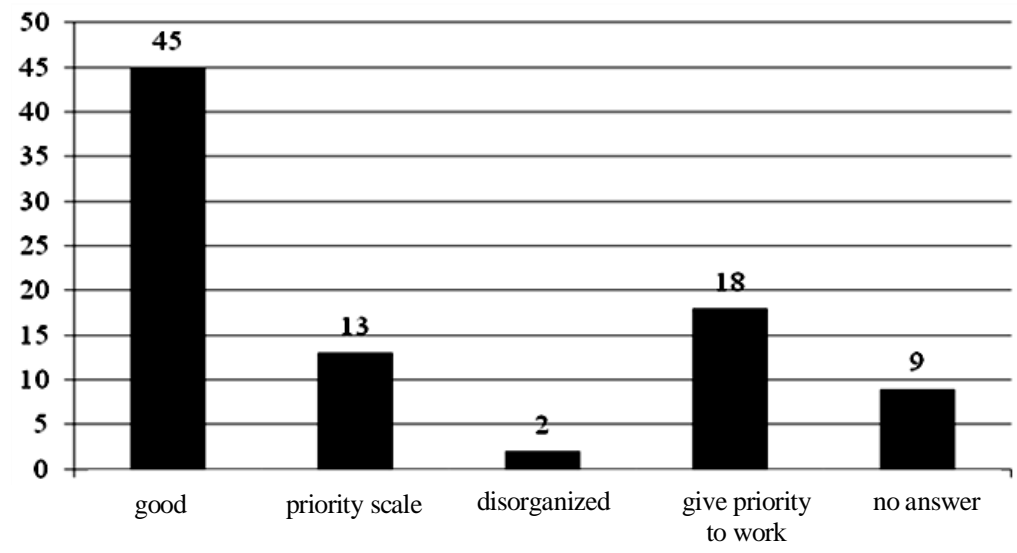

Figure 5. Graphic of time management.

School $\mathrm{Z}$ are classified in the mean range of $47.80-$ 41.53 with the $p>.05$. While High School Y and High School $\mathrm{Z}$ are classified in the mean range of $44.05-41.53$ with the $p>.05$.

Table 14 reveals that based on the difference testing result of Teachers' Self-Efficacy variable, there is no difference of mean between the three schools. The mean value of teachers' self-efficacy.

Table 15 indicates that there is no difference of the work engagement variable between the three schools based on the difference testing result. High School X and High School Y have the mean range of - 1.66615 with the $p>.05$. High School X and High School Z have the mean range of -.46377 with the $p>.05$. While High School Y and Hig School Z have the mean range of 1.20238 with the $p>.05$.

Table 16 shows that there is no difference between means based on difference testing of the Meaning of Work as a Calling variable in the three schools.

Table 17 shows that there is no difference in work engagement variable between the three schools based on the difference testing result. High School $\mathrm{X}$ and High School Y have the mean range of 0.60248 with the $p>.05$. High School X and High School Z have the mean range of -.29831 with the $p>.05$. While High School Y and High School Z have the mean range of -.90079 with the $p>.05$.

Figure 4 shows that there are 56 teachers who feel vigorous/eager when leaving for work. There are nine teachers who feel better when they are leaving for work. There is one teacher who feels that he will experience new things when leaving for work or in the other word, he is interested with the situation that will happen transpire in the school. There are 11 teachers who feel indifferent when leaving for work and the rest experience the feeling of worry (seven people) and do not answer (three people).

Figure 5 shows that 45 teachers state that they are able to manage their time for personal matters and work matters. But, 18 teachers also put their work as their priority.The priority scale is also used by 13 teachers. The other two teachers stated that they have 


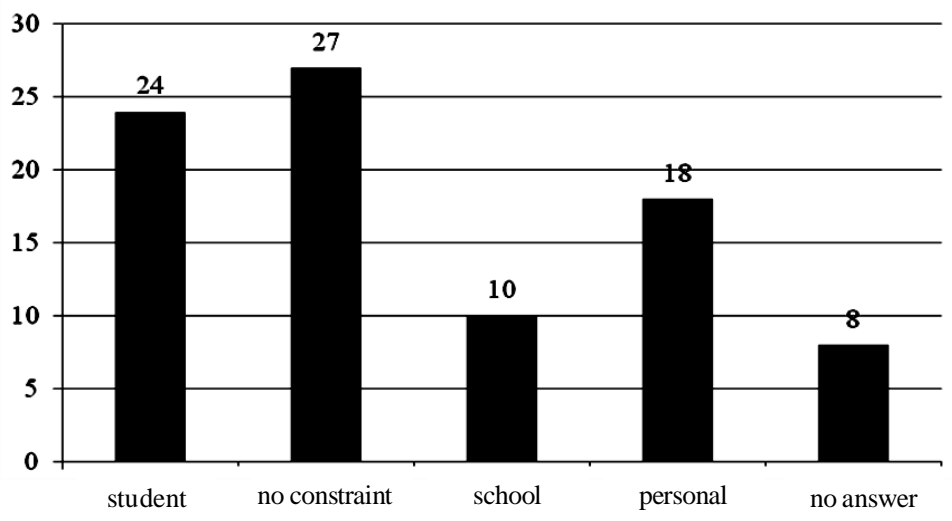

Figure 6. Graphic of working difficulties.

experienced difficulties in managing their time for personal and work matters, while the rest of the nice teachers did not answer.

Figure 6 indicates that 27 teachers claim that they do not experience difficulties during work, because they feel that working is a part of their worship. There are 24 teachers who experience difficulties when facing students who do not cooperate during the teachinglearning process, 18 find difficulties in their personal matters such as health and the lack of good time management. There are 10 who experience difficulties during work due to insufficient facilities in teaching.

Figure 7 indicates that 54 teachers state that they possess professional quality to teach, to guide, and to educate. There are 22 said they have moderate quality to work and three said their working competence is poor and needs improvement.

Figure 8 shows that 48 teachers have developed their competence through training, seminar, and workshop. As many as 31 teachers have developed their competence by innovating their teaching method through the exchange of ideas with colleague and their superior, searching on the Internet, and taking the next step of education which is the Master's degree. The rest of them (eight teachers) do not give their answers.

Figure 9 indicates that 38 teachers hope to improve their personal welfare such as to be more professional in teaching, and that this will impact the work engagement. There are 19 who hope for a development in the world of education such as the school facilities that support the teaching-learning process, while 12 hope for the improvement of students' quality. The other three hope for an improvement in all aspects such as personal welfare, school's development, and students' competence. The remaining 15 do not give their answer.

\section{Discussion}

\section{Teachers' Self Confidence and Work Engagement of Private School Teachers}

The hypothesis showed a significant correlation between teachers' self-efficacy and their engagement

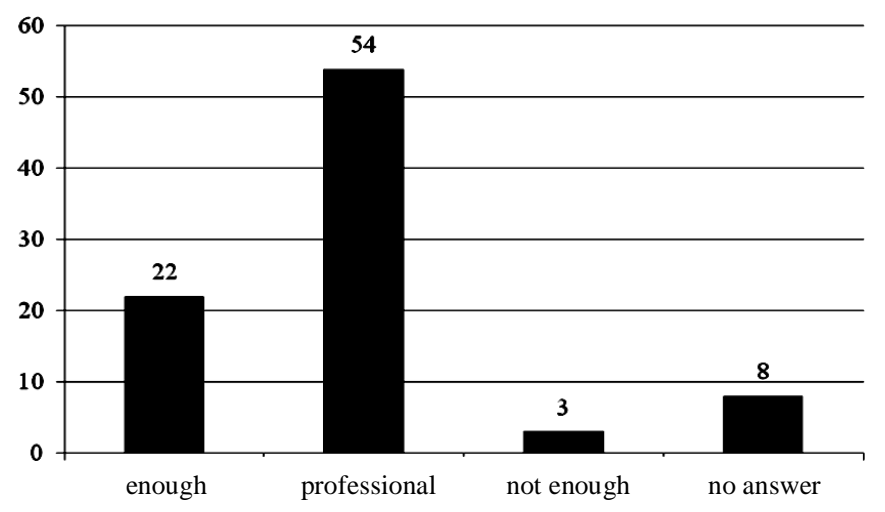

Figure 7. Graphic of teachers view on their ability. 


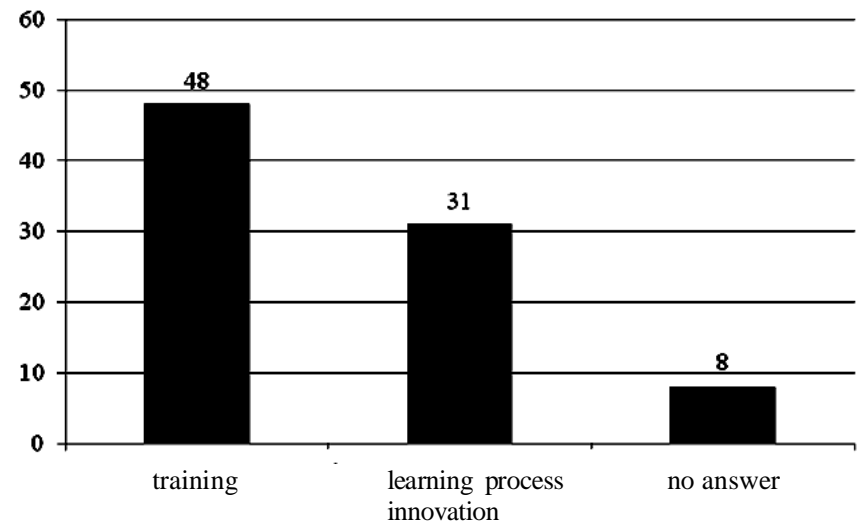

Figure 8. Graphic of teachers' competence development.

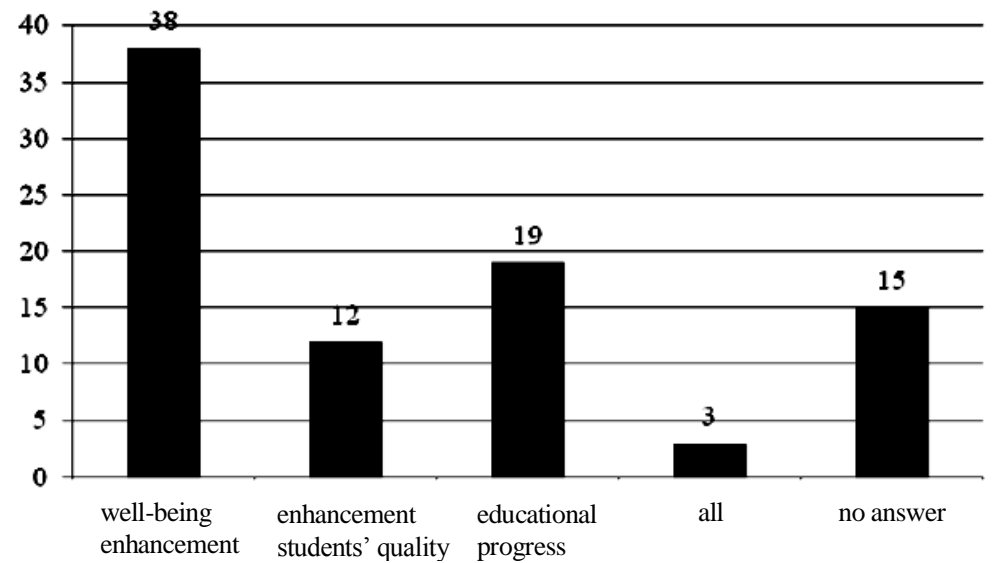

Figure 9. Graphic of teachers' hopes for the next five years.

to work $(r=.58 ; p<.05)$. This figure shows that teachers' self-efficacy is an important factor to determine work engagement. In the same manner shown by the JD-R model proposed by Bakker \& Demerouti (2008), it is now understood that work engagement is influenced by two resources and one of them is the psychological resources. Psychological resources are the aspects of the self that are generally associated with resilience and refer to the ability of an individual to control what factor(s) influence(s) his success in the environment (Hobfoll, Johnson, Ennis, \& Jackson, as cited in Xanthopoulou, et al., 2007). These resources are associated with positive self-evaluation that can predict life goals, motivation, performance, personal satisfaction and work, as well as desired outcomes (Judge et al., as cited in Bakker \& Demerouti, 2008).

One form of psychological resources is selfefficacy. Bandura's social cognitive theory (Schaufeli \& Salanova, 2007) defines self-efficacy as one's ability to organize and to execute as well as to produce an action that will deliver results. Schunk \& Meece (Skaalvik \& Skaalvik, 2009) stated that based on Bandura's concepts, it can be understood that selfefficacy impacts the aim and behavior of a person. Furthermore, confidence can be affected by environmental conditions. Beliefs determine how much opportunity a person can get from the environment in order to achieve his goals and how many obstacles that he needs to overcome (Bandura, as cited in Skaalvik \& Skaalvik).

Based on social cognitive theory, teachers' selfefficacy is conceptualized as teachers' belief in their ability to plan, organize, and perform the tasks needed in order to achieve a desired result in education (Skaalvik \& Skaalvik, 2009). A teacher who believes in his competence will be able to provide instructions that are easily understood by students, able to adjust teaching methods according to students' needs, able to motivate students, able to maintain an orderly and 
disciplined atmosphere in the classroom, able to collaborate with colleagues and parents, and able to cope with changes (Skaalvik \& Skaalvik).

In accordance to a research conducted by Xanthopoulou et al. (2007), this study conforms to the statement that an employee who is bound (or engaged) feels that $\mathrm{s} / \mathrm{he}$ is able to meet the demands and believes that it will result as a positive experience. This study also supports an earlier research conducted by E. M. Skaalvik \& S. Skaalvik (2009) on teachers' confidence. Self-confidence is a subjective perception of one's self and therefore teachers who think that they have had a positive experience will become more engaged to her/his occupation.

The result of the additional analysis (Figure 6) shows that the majority of teachers do not experience obstacles in completing tasks assigned by the schools' management. The constraint experienced by teachers is about the students who have been uncooperative during the teaching-learning process. The result of another additional analysis (Figure 7) shows that most of the teachers have the ability to professionally complete the tasks given by the school management. It can be seen from the perspective of the development of teachers' ability (Figure 8) that most teachers still want to improve their ability through various means such as training, seminars, workshops, exchange of ideas with colleagues and superiors, and to pursue further studies such as the Master's degree.

When teachers successfully complete the task from the school management, the teachers acquire the feeling of vigor (Figure 4) when they go to work and also obtain a good time management (Figure 5). Teachers who possessed self-efficacy in their ability will be able to complete the demands of work from school management, and therefore fulfill the educational goals and are more engaged to their profession as teachers.

The difference between this study and the research conducted by Simbula, Gugleimi, \& Schaufeli (2011) is the predictor variables of organizational resources (social support), the data retrieval that was done three times in four months, and the scale for teachers' selfefficacy refers to Di-Fabio \& Taralla (2003). This study uses psychological resources (teachers' selfefficacy) as the predictor variable, the data collection was done only once in almost two months, and the scale used is based on the theory of Skaalvik \& Skaalvik (2009). The assumption obtained relating to the teachers' work engagement between this study and the research conducted by Simbula, Guglielmi, \& Schaufeli (2011) was, that there is a significant correlation between teachers' self-efficacy and their work-engage- ment. This can only be attained by knowing the relationship between a teacher's self-efficacy and his work engagement, by utilizing the framework of JD-R models.

\section{Meaning of Work as a Calling and the Work Engagement of Private School Teachers}

Hypothesis test result shows a significant relationship between the meaning of work as a calling and the work engagement $(r=.612, p<.05)$. This suggests that the meaning of work as a calling has a substantial contribution when it comes to the engagement of work. This result supports the JD-R model (Bakker \& Demerouti, 2008) and a previous research conducted by Tanudjaja (2013) with $p<.05$. JD-R model proposed two resources that can affect work engagement; one of them is the psychological resources. Psychological resources are a positive self- evaluation that is associated with resilience and referred to individuals' ability to control and be successful in their environment (Bakker \& Demerouti, 2008).

Weiss, Skelley, Haughey, \& Hall (cited in Berg, Wrzesniewski, \& Dutton, 2010) argued that the meaning of work as a calling has a religious connotation, meaning that a person's work is a form of a service to God and also as a command and will of God. Someone who regards his works as calling would not be too concerned about financial award or raise (Bellah, Madsen, Sullivan, Swidler, \& Tipton, 1985). Wrzesniewski et al. (Berg, Wrzesniewski, \& Dutton, 2010) explained that individuals who do their work based on their calling would feel happy and enjoy the work with the belief that their work results will make the environment better. The meaning of work as a calling has impacts on individuals, work groups, and organizations (Wrzesniewski, 2003). Individuals who interpret their work as callings will provide more time, have better work results, and are more satisfied with their life and work environment; while workgroups and organizations will be more committed, the group processes will be healthier, they will more likely to have have optimal performance, and they will get more satisfaction towards colleagues and their own work.

The results of this study support the concept of Work Centrality that is understood as a general belief about the value of work in one's life (Miller, Woehr, \& Hudspeth, (2002). Work centrality has two perspectives about working, which are as a life role and a decision to select areas of interest. In accordance to the statement of Wrzesniewski, McCauley, \& Schwartz 
(Wrzesniewski, et al., 2003), the meaning of working as a calling is oriented at vigor and the gain of benefit from someone's job, which is associated with more time spent at work, getting more pleasure, and the increase of satisfaction towards one's work.

The findings of this study shows that most of the teachers who acquire the meaning of work as a calling feel that they do not face significant problems because the tasks of teaching, educating, and guiding students are acts of worship that should be implemented at the behest of God Almighty (Figure 6). Teachers' expectations for the next five years are the development of their potential, the advancement in the field of education such as the improvement of school facilities and infrastructure for the learning process, the increase of students' quality in areas of academic, non-academic, and behavior (Figure 9). Both have an impact on the work engagement, which shows on the majority of teachers who feel the vigor when they go to work (Figure 4) and manage their time well (Figure 5).

The study also examines differences in teachers' work engagement in the three schools. The difference in testing results of Kruskal-Wallis Test shows .647 ( $p$ $>.05$ ), which means that there is no significant difference in teachers' work engagement among the three schools (Table 14). High School X and High School Y have an average value of 47.80 and 44.05. These results indicate that the teachers' work enga-gement in High School X is higher than in High School Y.

High School $X$ and High School $Z$ have an average value of 47.80 and 41.53 . Based on these results, it is demonstrated that the teachers' work engagement in High School $X$ is higher than High School Z. In addition, the difference inteachers' work engagement in High School Y and High School Z shows that the teachers of High School $Y$ are more engaged to their work compared the teachers of High School Z.

The finding from the difference testing result on teachers' work engagement in three private schools shows that there are no significant differences between work engagements of the teachers in High School X, High School Y, and High School Z. This happens because each school was accredited as "A", having simillar vision and mission regarding to the development of students, and they are religion-based school.

The difference in testing on the teachers' selfefficacy variable shows that High School Y teachers have highest self-efficacy compared to the teachers from the other two schools, with a mean of 106.5357. Teachers' self-efficacy affects the work engagement. The work engagement of High School Y teachers comes in second position with a mean of 44.05. These results are consistent with the concept proposed by Bakker \& Demerouti (2008) that the psychological resources, specifically self-efficacy, have a positive correlation with work engagement.

The difference testing on the meaning of work as a calling variable shows that the teachers of High School X are ranked second with a mean of 24.4722 . The meaning of work as a calling has an influence on work engagement. Work engagement of teachers in High School $\mathrm{X}$ is ranked as first with a mean of 47.80. This is in accordance with the concept of the JD-R models proposed by Bakker \& Demerouti (2008), which state that psychological resources can be used as predictors of work engagement.

\section{Limitations}

The use of subjects' data was limited to the category of "calling," while it is best to be used as a whole, that is the meaning of work as calling, career, and job. During the preliminary data collection, the author did not uncover enough information about teachers' self-efficacy in facing managerial duties. The variable of self-efficacy uses a specific scale of self-efficacy, which is the teachers' self-efficacy with the goal of enriching their repertoire and to be closer to reality. Nevertheless, the teachers' self-efficacy scale has not been rationally validated as it was processed only using the logical validity. The process of data retrieval was performed by entrusting the questionnaire to the vice principal or public relations (PR) to be further distributed to the teachers. This unabled the author to make observations during the process of filling out the questionnaire. In addition, the author could not observe the dynamics of the subjects while they were filling the questionnaire.

\section{Conclusion and Suggestions}

Teachers' self-efficacy has a significant correlation with work engagement as shown by $r=.508$ with $p<$ .05. A teacher who has high self-efficacy also has a high engagement towards his work. The meaning of work as a calling has a significant correlation with work attachment as shown in $r=.612$ with $p<.05$. This means that the greater the meaning of the work found in a teacher who regards his job as a calling will result in greater engagement towards work. The findings reflect positive correlation between teachers' self-efficacy and their work engagement. Most teachers already have a high self-efficacy. Therefore, the 
school needs to conduct activities that support and increase the potential of teachers. Such activities may include seminars, trainings, and workshops. The school also needs to hold a gathering in order to refresh the teachers from the exhaustion of teaching, with the aim to reevaluate the true meaning of having the job as teachers. Teachers need to evaluate themselves concerning their motivation to work regarding to the meaning of work as a calling. It is better for the teachers to not only make sense of their works as God's calling and educating students, but as a life goal. Teachers should also explore their potentials, such as the upgrading of knowledge, including finding the right tips in creating a condusive classroom atmosphere.

\section{Further Research}

It is advised that the data collection should be done on individuals and the preliminary data collection can be completed with the results of the performance assessment from the schools and adding a number of subjects, with the aim to see the validated reliability scale.

\section{References}

Azwar, S. (2012). Penyusunan Skala Psikologi (2nd ed.). Jogjakarta: Pustaka Pelajar.

Bakker, A. B., \& Demerouti, E. (2007). The Job Demands-Resources model: State of the art. Journal of Managerial Psychology, 22(3), 309-28.

Bakker, A. B., \& Demerouti, E. (2008). Towards a model of work engagement. Career Development International, 13(3), 209-23.

Bandura, A. (1995). Self-efficacy in changing societies. Cambridge (United Kingdom): Cambridge University Press.

Bandura, A. (1977). Self-efficacy: Toward a unifying theory of behavioral change. Psychology Review, 84, 191-215.

Bandura, A., \& Locke, E. A. (2003). Negative selfefficacy and goal effects revisited. Journal of Applied Psychology, 88(1), 87-99.

Bandura, A., \& Wood, R. (1989). Effect of perceived controllability and performance standards on selfregulation of complex decision making. Journal of Personality and Social Psychology, 56(5), 805-814.

Baskin (2007). Vigor, dedication, and absorption: Work engagement among secondary school English teachers in Indonesia. Paper presented at the annual AARE Conference, 25th-29th November, 2007,
Freemantle, Perth, Western Australia.

Bellah, R. N., Madsen, R., Sullivan, W. M., Swidler, A., \& Tipton, S. M. (1985). Habits of the heart: Individualism and commitment in American life. New York, NY: Harper and Row.

Di-Fabio, \& Taralla, B. (2003). Measuring teacher self-efficacy: Psychometric properties of the Classroom and school context teacher self-efficacy scale (CSC-TSES). European Journal of School Psychology, 4(1), 51-74.

Dik, B. J., \& Steger, M. F. (2006, July). Work as a calling: Randomized trial of a calling based career development workshop. Paper presented at the National Career Development Association Global Conference, Chicago, IL.

Elangoven, A. R., Pinder, C. C., McLean, M. (2010). Callings and organizational behavior. Journal of Vocational Behavior, 76, 428-440.

Guru kok plagiat. (24 May, 2013). Retrieved from Kompasiana.com

Guru naik pangkat wajib mempunyai publikasi ilmiah. (23 August, 2013). Retrieved from Panduanguru.com

Hakanen, J. J., Bakker, A. B., \& Schaufeli, W. B. (2006). Burnout and work engagement among teachers. Journal of School Psychology, 43, 495-513.

Halbesleben, J. R. B. (2010). A meta-analysis of resources and work engagement: Relationships with burnout, demands, resources, and consequences. In A. B. Bakker \& M. P. Leiter (Eds.), Work engagement: A handbook of essential theory and research (pp. 102-117). New York: Psychology Press.

Hallberg, U., \& Schaufeli, W. B. (2006). "Same same" but different? Can work engagement be discriminated from job involvement and organizational commitment? European Psychologist, 11, 119-127.

Heuvel, M. v. d., Demerouti, E., Bert, H. J., Schreurs, B. H. J., Bakker, A. B., Schaufeli, W.B. (2009). Does meaning-making help during organizational change? Development and validation of a new scale. Retrieved from www.emeraldinsight.com/ 1362-0436.htm

Humas Dispendik Surabaya. (2013). Sosialisasi kurikulum 2013 dan jurnal online Dinas Pendidikan Surabaya. Retrieved from http://dispendik.surabaya. go.id/index.php/566-sosialisasi-kurikulum-2013dan-peluncuran-jurnal-on-line-dinas-pendidikankota-surabaya

Imam, S. S. (2007). General self-efficacy scale. Dimensionality, internal consistency, and temporal stability. Presented at the Redesigning Pedagogy: Culture, Knowledge and Understanding Conference, Singapore, May. 
Judge, T. A., Kluger, A. N., Locke, E. A., \& Durham, C. C. (1998). Dispositional effects on job and life satisfaction: The role of core evaluations. Journal of Applied Psychology, 83(1), 17-34.

Kahn, W. A. (1990). Psychological conditions of personal engagement and disengagement at work. Academy of Management Journal, 33(4), 692-174.

Klassen, R. M., Yerdelen, S., \& Durksen, T. L. (2013). Measuring teacher engagement: The development of the Engaged Teacher Scale (ETS). Frontline Learning Research, 2, 33-52.

Leiter, M. P., \& Bakker, A. B. (2010). Work engagement: Introduction. In A. B. Bakker \& M. P. Leiter (Eds.), Work engagement: A handbook of essential theory and research (pp. 1-9). New York: Psychology Press.

Llorens, S., Salanova, M., Schaufeli, W. B. \& Bakker, A. (2007). Does a positive gain spiral of resources, efficacy beliefs and engagement exist? Computers in Human Behavior, 23, 825-841.

Maslach, C., Schaufeli, W. B. \& Leiter, M. P. (2001). Job burnout. Annual Review of Psychology, 52, 397-422.

Miller, M. J., Woehr, D. J., \& Hudspeth, N. (2002): The meaning and measurement of work ethic: Construction and initial validation of a multidimensional inventory. Journal of Vocational Behavior, 60(3), 451-489.

Muhartoyo, I. (2009). Hubungan antara keyakinan diri (self-efficacy) dan keterikatan kerja (work engagement) dengan beban kerja (workload) dan kerja emosional (emotional labor) sebagai variabel moderator pada perawat RS Mitra Keluarga Surabaya (unpublished minithesis). Faculty of Psychology Universitas Surabaya.

Ouweneel, E., Le Blanc, P. \& Schaufeli, W. B. (2012). Don't leave your heart at home: Positive emotions, resources, and engagement at work. Career Development International, 16, 537-556.

PGRI akui ada guru malas mengajar. (2010, 11 Oktober). Retrieved from International Kompas.com

Tanudjaja, R. M. (2013). Hubungan antara konflik kerja, makna kerja sebagai panggilan, dan persepsi terhadap dukungan organisasional dengan keterikatan kerja (Unpublished mini-thesis). Faculty of Psychology, Universitas Surabaya.

Schaufeli, W. B., Bakker, A. B., \& Salanova, M. (2006). The measurement of work engagement with a short questionnaire: A cross-national study. Educational and Psychological Measurement, 66, 701-716.

Schaufeli, W. B., Salanova, M., González-Romá, V. \& Bakker, A. B (2002a). The measurement of engagement and burnout: A two sample confirmatory factor analytic approach. Journal of Happiness Studies, 3, 71-9.

Schaufeli, W. B., Martínez, I. M., Marques-Pinto, A., Salanova, M. \& Bakker, A. B. (2002b). Burnout and engagement in university students: A crossnational study. Journal of Cross-Cultural Psychology, 33, 464-481.

Schaufeli, W. B., \& Salanova, M. (2007). Efficacy or inefficacy, that's the question: Burnout and work engagement, and their relationship with efficacy beliefs. Anxiety, Stress \& Coping, 20, 177-196.

Schaufeli, W. B. \& Salanova, M. (2007). Work engagement: An emerging psychological concept and its implications for organizations. In S. W. Gilliland, D. D. Steiner., \& D. P. Skarlicki (Eds.) Research in social issues in management (Vol.5): Managing social and ethical issues in organizations (pp. 135-177). Greenwich, CT: Information Age Publishers.

Schaufeli, W. B., Taris, T., Le Blanc, P., Peeters, M., Bakker, A. B., \& De Jonge, J. (2001). Maakt arbeid gezond? Op weg naar een positieve Arbeids en Gezondheidspsychologie. De Psycholoog, 36, 422-428.

Schaufeli, W. B. \& Bakker, A. B. (2004). Job demands, Job resources, and their relationship with burnout and engagement: A multi-sample study. Journal of Organizational Behavior, 25, 293-315.

Scherbaum, C. A., Cohen-Charash, Y., \& Kern, M. J. (2006). Measuring general self-efficacy: A comparison of three measures using item response theory. Educational and Psychological Measurement, 66(6), 1047-1063.

Seligman, M. E. P., \& Csikszentmihalyi, M. (2000). Positive psychology : An introduction. American Psychology Association, 55(1), 5-14.

Shaukat, S., \& Iqbal, H. M. (2012). Teacher selfefficacy as a function of student engagement, instructional strategies and classroom management. Pakistan Journal of Social and Clinical Psychology, 10(2), 82-85.

Simbula, S., Guglielmi, D., \& Schaufeli, W. B. (2011). A three-wave study of job resources, selfefficacy, and work engagement among Italian school teachers. European Journal of Work and Organizational Psychology, 20, 285-304. doi: 10.1080/13594320903513916

Skaalvik, E. M., \& Skaalvik, S. (2009). Teacher selfefficacy and teacher burnout: A study of relations. Teaching and Teacher Education, 26, 1059-1069.

Tanudjaja, R. M. (2013). Hubungan antara konflik kerja, makna kerja sebagai panggilan, dan persepsi 
terhadap dukungan organisasional dengan keterikatan Kerja. (Unpublished mini-thesis). Faculty of Psychology, Universitas Surabaya.

Undang-Undang RI No.14 Tahun 2005. (2006). Guru dan Dosen. Bandung: Citra Utama.

Undang-Undang Sistem Pendidikan Nasional. (2003). Undang-undang Republik Indonesia nomor 20 tahun 2003 tentang pendidikan nasional. Bandung: Citra Utama.

Woodruff, S. L., \& Cahsman, J. F. (1993). Task, domain, reexamination of the self-efficacy scale. Psychological Reports, 72, 423-432.

Wrzesniewski, A., Dutton, J. E., \& Debebe, G. (2003). Interpersonal sense making and the meaning of work. Research in Organizational Behaviour, 25,
93-135.

Wrzesniewski, A., McCauley, C., Rozin, P., \& Schwartz, B. (1997). Jobs, careers, and callings: People's relations to their work. Journal of Research Personality, 31, 21-33.

Xanthopoulou, D., Bakker, A. B., Demerouti, E., \& Schaufeli, W. B. (2007). The role of personal resources in the Job Demands-Resources Model. International Journal of Stress Management, 14, 121-141.

Xanthopoulou, D., Bakker, A. B., Heuven, E., Demerouti, E., \& Schaufeli, W. B. (2008). Working in the sky: A dairy study among flight attendants. Journal of Occupational Health Psychology, 13, 345-356. 